Notre Dame Law School

NDLScholarship

Journal Articles

Publications

1994

\title{
Abortion/Reproductive Rights
}

Sandra S. Klein

Notre Dame Law School, klein.26@nd.edu

Follow this and additional works at: https://scholarship.law.nd.edu/law_faculty_scholarship

Part of the Legal Writing and Research Commons, Privacy Law Commons, and the Women's Health Commons

\section{Recommended Citation}

Sandra S. Klein, Abortion/Reproductive Rights, 13 Legal Reference Services Q. 87 (1994).

Available at: https://scholarship.law.nd.edu/law_faculty_scholarship/1154

This Article is brought to you for free and open access by the Publications at NDLScholarship. It has been accepted for inclusion in Journal Articles by an authorized administrator of NDLScholarship. For more information, please contact lawdr@nd.edu. 


\title{
YOUR RIGHT TO PRIVACY: SELECTIVE BIBLIOGRAPHIES
}

The following three bibliographies on the right to privacy are the first in a two part series on the subject. Part I covers Abortion/Reproductive Rights, Drug Testing/Use, and Employee/Employer privacy issues. Part II, which will appear in volume 13:4 of Legal Reference Services Quarterly, covers The Right to Die as an Issue of Privacy, Sexual Freedom and Your Right to Privacy, and Children's Rights/Family Rights.

\section{Abortion/Reproductive Rights}

Sandra S. Klein

\begin{abstract}
The issue of a woman's right to choose whether or not to continue with a pregnancy has proven to be complicated for many reasons, not the least of which is the implications for a person's right to do with her body as she sees fit. The bibliography that follows provides the researcher with an in depth look at this issue, with an emphasis on the privacy aspects.
\end{abstract}

Of the many privacy issues currently undergoing social scrutiny, abortion may well be the most significant; certainly, it has proven to be

Sandra S. Klein is Assistant Professor of Library Administration, University of Illinois Law Library, EdM, MSLIS, 504 East Pennsylvania Avenue, Champaign, IL 61820.

The author would like to thank Gregory E. High for his invaluable assistance.

Legal Reference Services Quarterly, Vol. 13(3) 1994

(c) 1994 by The Haworth Press, Inc. All rights reserved. 
one of the most problematic. Increasingly, pro and anti-choice adherents have moved to make this issue a litmus test for political "correctness." As a voting consideration, it has manifested itself as one of the primary single-issue considerations in local, state and national politics. Like the right to bear arms, the right to choice has become a significant political motivator for large segments of the population.

In the bibliography which follows, the abortion issue is considered from several perspectives. Unlike the issue of privacy, in its most general sense, and the Warren and Brandeis article that stands as the clear research foundation, the abortion issue seems to have no single written pillar on which all subsequent works stand. Scholarly evaluation of abortion appears largely to parallel the degree to which the issue has become a public one, with academic interest reflecting increasing social interest. Clearly in the last decade, particular interest in the area has arisen, as evidenced by the number of articles to be found in the periodical literature.

As the number of relevant journal articles has risen, the scope of evaluation has broadened. Scholars view the area from several perspectives; as might be expected given the importance of the issue. Bases of analysis have included constitutional, legal, social, religious, medical, family, political, and even work-related concepts, with a primary research direction subsumed under the overall privacy analysis. Because abortion rights have largely been based in caselaw (beginning with Roe $v$ Wade), the legal periodical literature is particularly rich in number and in analytical diversity.

The articles included in this bibliography provide an in-depth look at the issue of abortion as it relates to privacy as a legal and social concern. Limited to the last twelve years, (1980-1992), the articles cited, in conjunction with their own internal bibliographies, provide both a contemporary and a historical perspective on a matter of major public concem, and one whose emotional context will doubtless ensure its continuing importance to legal and social science scholars.

\section{ABORTION/PREGNANCY MONOGRAPHS}

Butler, J. Douglas and David F. Walbert, eds. Abortion, Medicine, and the Law. 3rd ed. New York, New York: Facts on File Publi- 
cations, 1986. This volume contains a collection of articles on the topic of abortion. It is divided into three parts: Law; Medicine; and, Ethics. Many of the articles include discussion of the relationship between a right to privacy and abortion. Both sides of the abortion issue are presented, along with discussions of the legal and ethical issues involved. (A 4th ed. has been published but was not available for inclusion in this bibliography.)

Cardozo, Benjamin N. Women's Annotated Legal Bibliography. Buffalo, N.Y.: William S. Hein and Company, 1990. Topical arrangement. Includes citations to articles that deal with issues related to privacy.

Cohen, Sherrill and Nadine Taub, eds. Reproductive Laws for the 1990's. Clifton, New Jersey: Humana Press, 1989. This volume contains the proceedings from a Forum on Reproductive Laws held in New York City on May 4, 1987, and some of the position papers that were prepared for the meetings. The work includes an index.

Goldstein, Robert D. Mother-Love and Abortion: A Legal Interpretation. Berkeley: University of California Press, 1988. The author argues that it is the unique, symbiotic relationship that exists between a woman and her growing fetus, that makes the right to choose whether or not to terminate a pregnancy imperative. A woman must have the right to choose to continue with the relationship and interdependency that will result from the carrying through of the pregnancy to term. A woman's right to make this decision privately is emphasized. The text of the work is written using an essay format which is supplemented by the use of extensive notes which include references to sources of information. There is also an extensive index.

Krason, Stephen M. Abortion: Politics, Morality and the Constitution: A Critical Study of Roe v. Wade and Doe v. Bolton and a Basis for Change. New York: University Press of America, 1984. Includes extensive index, and much discussion of the right to privacy.

Milbauer, Barbara, in collaboration with Bert N. Obrentz. The Law Giveth: Legal Aspects of the Abortion Controversy. New York: Atheneum, 1983. Traces the history of the abortion right in this 
country through case law in a way that is designed to be understandable to the lay person. Includes an index.

Rubin, Eva R. Abortion, Politics, and the Courts: Roe v. Wade and its Aftermath. Westport, Connecticut: Greenwood Press, 1982. Discusses the way "that the abortion law reformers have used the political process, especially the courts, to promote changes in the law."

Sloan, Irving J. The Law Governing Abortion, Contraception \& Sterilization. New York: Oceana Publications, Inc., 1988. Provides an historical perspective, in nontechnical language, for cases and statutes governing abortion. Appendices include: Selected State Abortion Statutes; and The Family Planning Services and Population Act.

Tribe, Laurence H. Abortion: The Clash of Absolutes. New York: W.W. Norton \& Company, 1990. The purpose of this book is to "explore the legal framework in which the constitutional question of abortion rights must be decided." The author traces the development of the right to privacy through Supreme Court decisions, and discusses the "implications of various competing constitutional theories for the abortion question and how judicial responses to abortion affect the fabric of other key constitutional rights: the right to raise our children as we see fit; the freedom of speech; the right to choose those with whom we will share our lives."

Wardle, Lynn D. The Abortion Privacy Doctrine: A Compendium and Critique of Federal Court Abortion Cases. Buffalo, N.Y.: William S. Hein and Co., Inc., 1980.

Wardle, Lynn D. and Mary Anne Q. Wood. A Lawyer Looks at Abortion. Provo, Utah: Brigham Young University Press, 1982. Provides an historical/legal perspective of the abortion controversy. Includes an index.

\section{PERIODICALS}

Abbot, Lisa. "Abortion regulation: the circumscription of state intervention by the doctrine of informed consent." Georgia Law 
Review 15 (Spring 1981): 681-713. “This Note will address the interaction of the state with the woman's decision-making process by focusing on the informed consent provisions which require the physician to disclose information to the abortion patient."

Allen, Anita L. "Taking Liberties: Privacy, Private Choice, and Social Contract Theory (Symposium: Feminist Moral, Social, and Legal Theory)." University of Cincinnati Law Review 56:2 (Fall 1987): 461-491. Among the strongest arguments advocating freedom of choice for women, insofar as reproductive decision making is concerned, are those based in the concept of privacy. Philosophically, such a privacy basis has been criticized as being "conceptually confused," too reflective of male ideology, or associated with one or another kinds of "judicial overreaching."

This author reacts to these charges by defending decisional privacy arguments, specifically by illustrating the importance of privacy as a tool for gaining and maintaining a new, higher level of rights for women, overall. Privacy is seen as an "elastic" concept, one applying to many aspects of individual rights, including a woman's right to choose abortion. The argument that "privacy" connotes female subjugation is also examined and found inadequate. Finally, David A. J. Richard's social contract theory of privacy rights for women is analyzed and found to have valuable application to the argument that permissive abortion laws make sound constitutional, as well as social sense.

Annas, George J. "The Impact of Medical Technology on the Pregnant Woman's Right to Privacy." American Journal of Law \& Medicine 13:2-3 (Summer-Fall 1987): 213-232. Concerned with the impact of advancing reproductive technology on a pregnant woman's right to privacy, this article notes that "constitutional interpretation has depended heavily on prevailing social and scientific views, as well as on advances in technology." An analysis of cases where "technology untempered by human rights" was held paramount is said to "lead to brutal dehumanization of pregnant women," with the only conclusion to be drawn that of the need to firmly establish human rights for women in law. 
"Predicting the Future of Privacy in Pregnancy: How Medical Technology Affects the Legal Rights of Pregnant Women (Symposium on Reproductive Rights)." Nova Law Review 13:2 (Spring 1989): 329-353.

Appleton, Susan Frelich. "Beyond the Limits of Reproductive Choice: the Contributions of the Abortion-funding Cases to Fundamental-rights Analysis and to the Welfare-rights Thesis." Columbia Law Review 81:4 (April 1981): 721-758. The author provides a review of abortion-funding cases, discusses the impact of such developments on fundamental rights analysis in general, and "upon the constitutional welfare-rights thesis in particular." The Court is, in effect, requiring the indigent citizen to look to the legislation, and not the courts or the Constitution, "for the satisfaction of some of even their most basic needs" (i.e., it is not enough to make abortion legal if the state will not provide funding for those women who cannot afford it on their own).

"Doctors, Patients and the Constitution: a Theoretical Analysis of the Physician's Role in 'Private' Reproductive Decisions." Washington University Law Quarterly 63:2 (Summer 1985): 183-236. The author argues that current cases give the Court the opportunity to disassociate the constitutional rights of women from those of their physicians. Thus far, it is argued, women's rights in this area have been tied to doctors and medical technology. "The abortion patient's rights, unlike the interests of her physician-however important the latter may be-have solid roots in the Constitution." This argument provides a framework to review reproductive freedom from an equal protection perspective.

Ashe, Marie. "Zig-Zag Stitching and the Seamless Web: Thoughts on 'Reproduction' and the Law." Nova Law Review 13:2 (Spring 1989): 355-384. A highly personal, idiosyncratic, perspective on the objectification of women in the birthing process. Considered here, are the social and legal contexts surrounding women and childbirth, the attitudes shown by medical, political, and legal personnel, the question of abortion, and, overall, the question of the moral validity of laws that regulate reproduction. 
Barnett, Bonnie Allyn. "Constitutional law-United States Supreme Court upholds the constitutionality of the Hyde Amendment, withholding Medicaid funds for therapeutic abortions unless the life of the mother is endangered." Temple Law Quarterly 54 (Winter 1981): 109-144.

Bradley, Thomas S. "Prohibiting Payments to Surrogate Mothers: Love's Labor Lost and the Constitutional Right of Privacy." John Marshall Law Review 20:4 (Summer 1987): 715-745. The author argues that a "married couple's decision to have a child through surrogate motherhood is constitutionally protected under the rights of privacy from undue state infringement." He goes on to argue that laws preventing payment of the surrogate infringe upon this right to privacy, and that the state's interests would be better served by licensing, bond requirements and regulation.

Brill, Alida. "Part One: Family Secrets," and "Part Two: "The Opening of the American Womb" in Nobody's Business: Paradoxes of Privacy. Reading, Mass.: Addisson-Wesley Publishing Company, 1990. pp. 3-95. The 1973 Roe $v$ Wade decision gave women the right to choose to have an abortion and placed that right within the realm of privacy. Of all of the Supreme Court privacy decisions, this has been the most controversial. What was once a private, family, decision (how to deal with an unwanted pregnancy), is now out in the open, and part of political debate.

Boatwright, David C. "Where for art thou Danforth: Bellotti v. Baird." Pepperdine Law Review 7 (Summer 1980): 965-982. This article deals with the question of the conflicting interests of minors, their parents and the state in the issue "of a minor's right to make an independent decision with respect to abortion."

Bopp, James. "Will there be a constitutional right to abortion after the reconsideration of Roe v. Wade?" (in Webster v. Reproductive Health Services) Journal of Contemporary Law 15 (Fall 1989): 131-173.

Bridge, Burneatta. "Parent versus child: H.L. v. Matheson and the new abortion litigation." (case note) Wisconsin Law Review 1982 (January-February 1982): 75-116. This article presents an historical analysis of recent (1982) Supreme Court decisions on the 
topic of a "minor's procreative autonomy," and examines the constitutionality of parental notification laws.

Broden, F. Clinton. "Emergency Room Surgery on Abortion Rights." The Journal of Law \& Politics 6:4 (Summer 1990): 827-853. Several states now have constitutions that explicitly grant privacy rights to citizens. In a period of declining liberal judicial interpretation on the part of the federal Supreme Court, it may be left to state courts to interpret state constitutional guarantees of privacy relative to the abortion issue. If Roe $v$ Wade is overturned or interpreted in conditional fashion by an increasingly conservative Supreme Court, litigants might look to state courts to interpret state constitutional guarantees of privacy as protective of women's rights.

Brown, Jason H. "Abortion-right to abortion remains unstable." (case note) Suffolk University Law Review 21 (Fall 1987): 877-889. Discusses the case of Thornburgh v. American College of Obstetricians and Gynecologists, 106 S.Ct. 2169 (1986), in which the Supreme Court reviewed a Pennsylvania Abortion Control Act. The purpose of this Act was to regulate the "information a woman considers before consenting to an abortion, the procedure a physician follows when performing a late abortion, and the data that is reported to public authorities." The Supreme Court held that this Act violated a woman's right to privacy. The article continues with an historical review of abortion regulations that have been reviewed by the Supreme Court.

Brown, Phyllis. "Abortion and the Thirteenth Amendment: A return to reason." Journal of Juvenile Law 5 (1981): 137-147. Traces the history of statutory and case law, emphasizing the author's viewpoint that a woman's right to an abortion is, or should be, protected under the Ninth amendment which "insures" a right to privacy.

Brueschke, Erich and Jason Brueschke. "Constitutional law: the future of the abortion controversy and the role of the Supreme Court." (Case Note) Oklahoma Law Review 43 (Fall 1990): 481-513. Discusses the effects of Webster $v$ Reproductive Health Services, 109 S. Ct. 3040 (1989), on a woman's “constitutional right and ability to seek unrestricted abortions." 
Buchanan, Elizabeth. "The Constitution and the anomaly of the pregnant teenager." Arizona Law Review 24 (Summer 1982): 553-610. The author discusses the "special problems of teenage pregnancy and the interests in conflict in the teenage abortion cases." She then goes on to analyze the attempts of the Supreme Court to address these problems and accommodate all of the interests involved, in an effort to determine why the Court has failed to come up with a "workable resolution."

Beutler, Mark J. "Abortion and the Viability Standard: Toward a More Reasoned Determination of the State's Countervailing Interest in Protecting Prenatal Life." Seton Hall Law Review 21:2 (1991): 347-386. In Roe v Wade (410 US 113, 1973), the Court held that a Texas statute forbidding abortion except to protect the mother's life, was unconstitutional. The Court considered only two interests as legitimate areas of concern for a state to impose regulation of abortion: the protection of maternal health, and the potential of human life. This note examines the conceptual framework in which Roe is grounded, especially the concern over the moment of fetal viability. The author contends that the viability standard expressed in Roe needs to be reexamined, arguing that the trimester scheme is unsatisfactory as a means of explanation as to "why the state's interest in fostering prenatal life is not compelling prior to viability."

Bush, Susan A. "Parental notification: a state-created obstacle to a minor woman's right of privacy." Golden Gate University Law Review 12 (Summer 1982): 579-603.

Byrne, Jr., Thomas J. "The right to abortion limited: the Supreme Court upholds the constitutionality of parental notification statutes." (case note) Loyola Law Review 28 (Winter 1982): 281-296.

Capron, Alexander Morgan. "Choosing Family Law Over Contract Law as a Paradigm for Surrogate Motherhood." Law, Medicine \& Health Care 16 (Spring-Summer 1988): 34-43.

Casurella, Jeffrey Giles and Carrie Tyrrell Shrock. "The trimester approach: how long can the legal fiction last?" Mercer Law Review 35 (Spring 1984): 891-913. Provides an analysis of key abortion decisions, and examines the debate which surrounds the 
trimester approach in an attempt to determine whether or not a different approach is preferable and feasible.

Chemerinsky, Erwin. "Rationalizing the abortion debate: legal rhetoric and the abortion controversy." Buffalo Law Review 31 (Winter 1982): 107-164. Presents an analysis of the Supreme Court's decision in Roe $v$ Wade. In the first section, five possible approaches to the issue of abortion are analyzed. In the second section the author examines the constraints placed upon the Supreme Court by the need of the Court to explain its decisions to the public, and this fact, the author concludes, makes the Court's Roe decision understandable. It is further argued that we must examine the arguments, the rhetoric, used in support of a decision very carefully, especially in light of the fact that there is seldom a "right" answer to a constitutional question.

Clement, Susan et al. "The evolution of the right to privacy after Roe v. Wade." (Justice Harry A. Blackmun: the Supreme Court and the Limits of Medical Privacy) American Journal of Law \& Medicine 13 (Summ-Fall 1987): 365-525. This note offers an extensive historical/legal perspective on the privacy issue following Roe $v$ Wade. Several areas of evaluation are offered, including the concept of bodily autonomy, abortion law and funding, sexual privacy, and pregnancy discrimination in the workplace.

Cohen, Leslie Ann. "Fetal viability and individual autonomy: resolving medical and legal standards for abortion." UCLA Law Review 27 (August 1980): 1340-1364. The author argues that the fetal viability standard established in Roe and subsequent decisions, in which viability is defined as "the ability to survive outside the womb with or without artificial aid," must be re-evaluated in light of present and future advances in medical technology which allow for the increased likelihood of fetal viability at earlier stages of fetal development. She argues for an objective standard "to protect a fetus which is reasonably likely to survive without artificial aid, but not a fetus in need of artificial gestation."

Copelon, Rhonda. "Losing the negative right of privacy: building sexual and reproductive freedom." (The Nation Institute Confer- 
ence: The Supreme Court and Daily Life; Who Will the Court Protect in the 1990s?) New York University Review of Law \& Social Change 18 (March 1990): 15-50. Concerned with "a power which is fundamental in our traditional, liberal, constitutional scheme: the control over one's body and the direction of one's life," this article explores sexual and reproductive freedom issues from the perspectives of legal attacks on the right to abortion, the political context and constitutional interpretation, and the role and limitations of the privacy approach as the vehicle for protecting access to abortion.

Following the line of decisions that systematically restricted abortion rights, consideration is given to the Medicaid funding decisions, to cases dealing with sexual self-determination, to parental rights, and to the conservative choice of judicial appointments. Discussion relative to privacy as a tool in securing true moral and physical autonomy is considered at some length, with emphasis on the fact that "privacy" must be seen as more than merely "the right to be left alone. Privacy must be transformed into an affirmative right to self-determination, grounded in the broader principle of equality and the concrete condition of reality."

Crawford, Linda D. "Constitutional law-privacy rights-consent requirements and abortions for minors." New York Law School Law Review 26 (Summer 1981) 837-854.

Crusius, Carla J. "Constitutional law-right to privacy-municipal roadblock to abortion denounced-City of Akron v. Akron Center for Reproductive Health, Inc. 103 S.Ct. 2481 (1983)" Seton Hall Law Review 14 (Summer 1984): 658-682.

Czarnecki, Mary Sue. "Constitutional law-a minor's abortion right under a parental notice statute." (case note) Wayne Law Review 28 (Summer 1982): 1901-1928.

Earll, Jane M. "City of Akron v. Akron Center for Reproductive Health, Inc.: A weakening of the trimester approach to abortion regulation." Ohio Northern University Law Review 11 (Winter 1984): 181-202.

Emerson, Thomas I. "The power of Congress to change constitutional decisions of the Supreme Court: the human life bill." 
Northwestern University Law Review 77 (April 1982): 129-142. Discusses legislation known as the Human Life Bill which has been proposed by opponents of abortion rights. The author argues that this bill raises important constitutional issues regarding the "legal effect of congressional 'findings of fact' and declarations of law and with the extent of congressional powers under section 5 of the fourteenth amendment." The author concludes that not only is this Bill unconstitutional, but that the arguments in favor of it pose a major threat to the structure of our constitutional system.

Erickson, Nancy S. "Reproduction and the law." Medical Trial Technique Quarterly 32 (Fall 1985): 165-174. Deals with the privacy aspects of cases involving reproductive decisions.

Erca, Alison. "Committee to Defend Reproductive Rights v. Myers: procreative choice guaranteed for all women." (case note) Golden Gate University Law Review 12 (Summer 1982): 691-716. "This note will trace the development of the right to privacy as applied to abortion funding and as interpreted by the United States and California Supreme Courts."

Ezzard, Martha M. "State Constitutional Privacy Rights Post Webster-Broader Protection against Abortion Restrictions?" Denver University Law Review 67:3 (1990): 401-419. Following Webster $v$ Reproductive Health Services, 109 S. Ct. 3040 (1989), it became clear that states might restrict a woman's right to abortion, irrespective of Roe $v$ Wade, 410 U.S. 113 (1973). This consideration of the issue suggests that "state constitutional privacy guarantees can be expected to defend against greater restrictions on abortion which will continue to be proposed by state legislatures in the post-Webster period." The author includes suggestions for constructing "model" state constitutional privacy amendments, and a list of those state constitutions which already contain such amendments.

Fernandez, David. "Thornburgh v. American College of Obstetricians: return to Roe?" (case note) Harvard Journal of Law \& Public Policy 10 (Summer 1987): 711-727.

Ford, Nancy. "The evolution of a constitutional right to an abortion, fashioned in the 1970s and secured in the 1980s." Journal of 
Legal Medicine 4 (September 1983): 271-322. The 1973 decision in Roe $v$ Wade was made in the context of a trend toward the liberalization of abortion laws. Other cases followed Roe in expanding and affirming a woman's right to physical self-determination. This article focuses on the "historical evolution of the right to an abortion" with primary attention given "to the various standards of judicial review" that have been used by the courts. The constitutionality of specific types of abortion regulation is analyzed as well, at all court levels. Finally, the article concludes that a right to abortion is secured in light of the Supreme Court's review of three cases: City of Akron $v$ Akron Center for Reproductive Health, Inc., Planned Parenthood Association v Ashcroft, and Simopoulos $v$ Virginia, all decided in 1983.

It should of course be noted that this article reflects rulings only to 1983 , and that an analysis of later decisions clouds what appears to be a clearcut judicial support of this right to abortion.

Garfield, Helen. "Privacy, abortion, and judicial review: haunted by the ghost of Lochner." Washington Law Review 61 (April 1986): 293-365.

Goldstein, Leslie Friedman. "A critique of the abortion funding decisions: on private rights in the public sector." Hastings Constitutional Law Quarterly 8 (Winter 1981): 313-342. The author argues that the Court's decisions which have held that it is permissible for a state to deny public funding of abortions, in effect, eliminates the option of abortion for those women whose lives will be the most effected by the imposition of an unwanted pregnancy; and, suggests alternative approaches for the Court to take in "defining the proper relationship between "negative" constitutional freedoms and governmentally conferred benefits."

Graham, M. Louise. "Surrogate Gestation and the Protection of Choice." Santa Clara Law Review 22 (Spring 1982): 291-323. Discusses the question of whether or not surrogacy falls under the rights of privacy and procreational choice.

Grant, Edward R. "Conclusion: the future of abortion as a "private choice." (The Webster Amicus Curiae Briefs: Perspectives on the Abortion Controversy and the Role of the Supreme Court) 
American Journal of Law \& Medicine 15 (Summer-Fall 1989): 233-243.

Gray, Karen F. B. "An Establishment of Religion Clause Analysis of Webster v. Reproductive Health Services." Georgia Law Review 24:2 (January 1990): 399-421. Argues that the Supreme Court made an error in its decision in the Webster case because eight of the nine justices ignored the clear violation of the establishment clause inherent in the preamble of the Missouri statute. The author argues that the court should have emphasized the importance of not showing favoritism to a religious sect, or religion itself. In upholding this statute, the court allowed the Missouri legislation to create the perception by some of the state's citizens that their government endorsed the religious views of the anti-abortion faction. The preamble to the statute includes, for example, a statement that life begins at conception.

Greene, Judith. "Spousal notice-weighing the burden on a woman's abortion decision." Stetson Law Review 12 (Fall 1982): 250-264.

Haas, Eric M. "Webster, privacy, and RU486. (abortion pill)" The Journal of Contemporary Health Law and Policy 6 (Spring 1990): 277-296. The author reviews the Supreme Court's decision in Webster v Reproductive Health Services, 109 S.Ct. 3040 (1989), and discusses the possible effects of this decision on the regulation of abortions by the states. The "abortion pill," RU486, a drug which stimulates miscarriage, is discussed in this context, and the author proposes "a model statute to demonstrate the expanded possibilities of constitutional state abortion regulation." That is, the regulation of the use of the drug RU486.

Hebert, Catherine. "Prohibition of Public Funding for Abortion Counseling: Government Violation of Women's Constitutional Right of Privacy." Hastings Constitutional Law Quarterly 17:2 (January 1990): 421-437.

Hewitt, Selina Katherine. "Chipping Away at Roe v. Wade in the Aftermath of Webster." (Case Note) Pepperdine Law Review 18 (May 1991): 955-1010. Traces the "history and evolving status of permissible state regulation of the abortion decision." 
Horan, Dennis J., Clarke D. Forsythe and Edward R. Grant. “Two ships passing in the night: an interpretavist review of the WhiteStevens colloquy on Roe v. Wade." (Bicentennial Tribute to the United States Constitution) Saint Louis University Public Law Review 6 (Fall 1987): 229-311. The purpose of this article is to review the historical and legal premises of the Roe decision, and to discuss the concurring opinion of Justice Stevens and the dissenting opinion of Justice White in the case of Thornburgh $v$. American College of Obstetricians and Gynecologists, $106 \mathrm{~S}$. Ct. 2169 (1986).

Johnsen, Dawn. "Shared Interests: Promoting Healthy Births Without Sacrificing Women's Liberty." Hastings Law Journal 43:3 (March 1992): 569-614.

Johnsen, Dawn, and Marcia Wilder. "Will Roe v. Wade Survive the Rehnquist Court?" Nova Law Review 13:2 (Spring 1989): 457-469. In 1973, the Supreme Court issues its decision in Roe v Wade, a decision that has undergone progressively greater scrutiny with the advent of an increasing political conservatism. The authors indicate that "no other judicial decision has had a more profound and positive effect on the lives and health of American women," and that to overturn Roe would be to cause exactly the kind of harm to women and unwanted children that existed prior to the decision. Roe, and those cases following it, are examined in some detail, with special emphasis placed on those cases involving a state's attempt to restrict the rights of women to seek or have an abortion.

Johnson, Amy. "Abortion, personhood, privacy in Texas." (Symposium on the Texas Constitution) Texas Law Review 68 (June 1990): 1521-1544. The Texas Supreme Court has made it clear "that the Texas constitution guarantees the right to privacy." The author argues that the confirmation of this constitutional guarantee of privacy "compels the state decision makers to recognize the validity of a Texas woman's right to choose an abortion."

Jordan, James M. III. "Incubating for the State: the Precarious Autonomy of Persistently Vegetative and Brain-dead Pregnant Women." Georgia Law Review 22:4 (Summer 1988): 1103-1165. 
Karr, Gwen Snyder. "Constitutional law: the minor's right to consent to abortion: how far is Oklahoma from Akron?" Oklahoma Law Review 37 (Winter 1984): 780-809. Discusses the "current status of the Oklahoma law governing the minor's right to consent to abortion in light of the Supreme Court's most recent [1983] decision in Akron $v$ Akron Center for Reproductive Health, Inc."

Kendall, Christopher C. "Shhh . . . don't say the "A" word! Another outcome-oriented abortion decision." (Case Note) John Marshall Law Review 23 (Summer 1990): 753-770. Discusses the fact that in the case of New York $v$ Sullivan (889 F.2d 401 (1989)) the Second Circuit Court of Appeals wrongly concluded that the constitutional rights of women to privacy and to choose to have an abortion were not violated by regulations prohibiting federally funded health clinics "from engaging in non-directive counseling and referral of women for abortion." The author argues that the Court came to the "wrong conclusion because it failed to comprehend the nature of the privacy right at issue."

King, Patricia. "Should Mom be Constrained in the Best Interests of the Fetus?" Nova Law Review 13:2 (Spring 1989): 393-404. This article considers whether "pregnant women (should) be compelled to act in the best interests of their fetuses." The author explores the relationship between the pregnant woman and her unborn child, looking in detail at moral, legal, and privacy issues.

Knicely, James J. "The Thornburgh and Bowers Cases: Consequences for Roe v. Wade." Mississippi Law Journal 56:2 (August 1986): 267-323.

Kudner, Kathrin E. "A decade of cementing the mosaic of Roe v. Wade: is the composite a message to leave abortion alone?" University of Toledo Law Review 15 (Winter 1984): 681-753.

Kunz, Kimberly A. "A thorn in the side of privacy: the need for reassessment of the constitutional right to abortion." (In Celebration of Our Constitution: with text of the United States Constitution) (case note) Marquette Law Review 70 (Spring 1987): 534-571. "This comment examines the historical background of abortion issues prior to Thornburgh, briefly outlining the development of legal precedents concerning abortion legislation, and 
noting the changing standards of judicial scrutiny applied by the Court." The author presents an overview of the Thornburgh decision, and analyzes the impact of the scrutiny standards used in that decision on the scope of the abortion right.

Leone, Ed. "Finding the cost of freedom." Ohio Northern University Law Review 8 (April 1981): 388-398. In this case, Harris $v$ McRae (100 S.Ct. 2671 (1980)), the plaintiff was challenging the restrictions placed on federally funded abortions by the Hyde Amendment. This amendment restricted funding to abortions that were to be performed because the mother's life would be endangered, and to the victims of rape and incest. In effect, because the financially needy are dependent upon the government for medical care, it could be argued that their options are limited by the availability of funding. In this case, the Court concluded that "although there was a constitutional right to decide, free from governmental interference, to have an abortion ... there was not a corresponding right to a free abortion."

Lim, Diana G. "Right of privacy-mandatory hospitalization for all second trimester abortions invalidated as not being reasonably related to maternal health." Santa Clara Law Review 24 (Summer 1984): 789-801.

Lobman, Helaine F. "Spousal notification: an unconstitutional limitation on a woman's right to privacy in the abortion decision." Hofstra Law Review 12 (Winter 1984): 531-560.

Lopez, Antoinette Sedillo. "Privacy and the Regulation of the New Reproductive Technologies: a Decision-making Approach." Family Law Quarterly 22:2 (Summer 1988): 173-197.

Martyn, Ken. "Technological advances and Roe v. Wade: the need to rethink abortion law." UCLA Law Review 29 (June-August 1982): 1194-1215.

Matteo, Melissa A. "Governmental abortion policies and the right to privacy: the rights of the individual and the rights of the unborn." Brooklyn Journal of International Law 11 (Winter 1985): 103-126. 
McArthur, John R. "Constitutional law-Supreme Court is undecided on parental notification requirement for minor's abortion." South Carolina Law Review 31 (February 1980): 604-616.

McCarthy, J. P. "Constitutional law-right to privacy-parental notice requirements in abortion statutes." Tennessee Law Review 48 (Summer 1981): 974-999.

Mertus, Julie A. "Challenging fake abortion clinics: protecting women's privacy interests without violating the First Amendment." New York University Review of Law \& Social Change 15 (June 1987): 547-579.

Miller, Gail Harrington. "H.L. v. Matheson: can parental notification be required for minors seeking abortions?" (case note) University of Richmond Law Review 16 (Winter 1982): 429-447.

Moore, Sally Anne. "Constitutional law-right of privacy-abortionfamily law-parent and child-standing-as applied to immature, unemancipated and dependent minors, a state statute requiring a physician to notify a pregnant minor's parents prior to the performing of an abortion is constitutional." (case note) University of Cincinnati Law Review 50 (Fall 1981): 867-881.

Myers, Richard S. "The End of Substantive Due Process?" Washington and Lee Law Review 45:2(Spring 1988): 557-621. Discusses the court's extension of the right of substantive due process to create a constitutional right of privacy, to protect a woman's decision to have an abortion, and to protect access to contraceptives.

Neff, Christyne L. "Woman, Womb, and Bodily Integrity." Yale Journal of Law and Feminism 3 (Spring 1991): 327-353. The author argues that the privacy right relied upon in safeguarding a woman's right to have an abortion, has proved to be inadequate because it allows the fetus to be treated as an entity separate from the woman whose womb it inhabits. What is needed, she suggests, is a legal analysis that acknowledges the physical reality of women's lives; that is, that women do not exist separately from their wombs. The principle she suggests is "the security of one's physical liberty, or bodily integrity, from government violation." 
Nocon, James J. "Physicians and Maternal-Fetal Conflicts: Duties, Rights and Responsibilities." Journal of Law and Health 5:1 (1990-91): 1-34.

O'Connor, Catherine. "Abortion funding restrictions: state constitutional protections exceed Federal safeguards." Washington and Lee Law Review 39 (Fall 1982): 1469-1489.

Oberman, Michelle. "Sex, Drugs, Pregnancy, and the Law: Rethinking the Problems of Pregnant Women Who Use Drugs." Hastings Law Journal 43:3 (March 1992): 505-548.

Olmstead, Frank H. "Abortion choice and the law in Vermont: a recent study." Vermont Law Review 7 (Fall 1982): 281-313.

Olsen, Frances. "Comment: Unraveling Compromise." Harvard Law Review 103:1 (November 1989): 105-135. Discusses the traditional analysis that the right to choose abortion is a right protected by the privacy guarantees implicit in the fourteenth amendment due process clause, and considers the alternative analysis which bases the right to abortion in the equal protection clause of the fourteenth amendment.

Paltrow, Lynn M. "Women, Abortion and Civil Disobedience." Nova Law Review 13:2 (Spring 1989): 471-479. Under George Bush's presidency, the question of the criminalization of abortion has reappeared with certain immediacy. This article asks whether or not abortion can be considered the making of a conscious political statement, that is, a willful act of civil disobedience.

Prall, Susan. "State Attempts to Regulate Abortion." Survey of American Law 1988:2 (Summer 1988): 385-427.

Quinn, Mary E. "State abortion statutes and their compliance with Roe v. Wade: the battle continues." (case note) Creighton Law Review 20 (Winter 1987): 917-948.

"Refusal to fund constitutionally protected right held valid: Harris v. McRae, 100 S.Ct.2671 (1980)." Washington University Law Quarterly 59 (Spring 1981): 247-260. See Leone, this bibliography.

Renfer, Susan Oliver, Randal Shaheen and Michael Hegarty. "The Woman's Right to Know: A Model Approach to the Informed 
Consent of Abortion." Loyola University Law Journal 22:2 (Winter 1991): 409-444. In light of the Supreme Court's decision in Webster v Reproductive Services (109 S.Ct. 3040, 1989, recognizing that states may legislate regarding medical standards for abortion practice), this article offers a Model Woman's Informed Choices Act for use by states choosing to draft such anti-choice legislation.

Rhoden, Nancy K. "Trimesters and technology: revamping Roe v. Wade." Yale Law Journal 95 (March 1986): 639-697. The author provides a review of the justification for, and usefulness of, the division that the Supreme Court established between the first and second trimesters; and discusses the implications of advances in medical technology in the area of fetal viability, concluding that there must be a time range that is not controlled by technology in order to allow sufficient time for a woman to exercise her constitutional right to an abortion.

Richards, David A. J. "Constitutional Legitimacy and Constitutional Privacy." New York University Law Review 61:5 (November 1986): 800-862. The author examines two constitutional privacy cases: Thornburgh $v$ American College of Obstetricians and Gynecologists and Bowers $v$ Hardwick, and provides discussion on the "proper scope of constitutional interpretation" by the Supreme Court.

Richards, David A. J. "Constitutional Privacy, Religious Disestablishment, and the Abortion Decisions" In Abortion: Moral and Legal Perspectives. Amherst, Mass.: University of Massachusetts Press, 1984, pp. 148-174. Includes bibliography.

Ricks, Sarah. "The New French Abortion Pill: The Moral Property of Women." Yale Journal of Law and Feminism 1:1 (Spring 1989): 75-99. The drug known as RU 486 was designed to induce abortion in the very early stages of pregnancy. The introduction of this drug has been met with controversy in many nations including the United States, where the drug has not yet been approved for use. The drug, once approved could be used for purposes other than that of abortion. But the fact of its potential use as an abortifacient is a major stumbling block in the approval process. 
The author argues that the drug ties in with the right to privacy arguments used in the Roe decision. Not only would a woman have the right to choose to have an abortion, but with this drug, she could induce the abortion herself in the privacy of her own home. The autonomy of women, she argues, is dependent upon the right to exercise control over ones own body. The drug, RU 486 , gives women another option, and thus, more control.

Ridder, Stephanie, and Lisa Woll. "Transforming the Grounds: Autonomy and Reproductive Freedom." Yale Journal of Law and Feminism 2:1(Fall 1989): 75-98. The authors argue that a woman must have the right to decide whether or not to have a child without the interference of any other party. A woman's right to autonomy has to include the right to self-determination and bodily integrity.

Riley, Brian W. "Constitutional law-substituted judgment in Rhode Island: preserving a mentally incompetent woman's right to an abortion." (Annual Survey of Rhode Island Law) (case note) Suffolk University Law Review 22 (Summer 1988): 397-413.

Robeen, Gina K. "Laws Like White Elephants: Sterilization of the Right to Privacy." SMU Law Review 46:1 (Summer 1992): 57-83. The article begins with a "brief discussion of the origins of the general right to privacy. It then traces the development of the right as it pertains to reproductive issues: first, in establishing and defining a woman's right to privacy; second, in analyzing current attempts to define those rights more closely; and third, in balancing women's reproductive rights against other legitimate state interests." Finally, this comment focuses on constitutional objections to using Norplant, a contraceptive implant for women, and the possible outcome of Supreme Court decisions on court imposed use of this contraceptive.

Roberts, Dorothy E. "Punishing Drug Addicts Who Have Babies: Women of Color, Equality, and the Right of Privacy." Harvard Law Review 104:7 (May 1991): 1419-1482. A large number of women, mostly black, "have been charged with criminal offenses after giving birth to babies who test positive for drugs." The author contends that such prosecution is racially motivated 
and infringes upon the rights of women of color to choose motherhood while being addicted to drugs.

Robinson, Robert C., and Paul M. Kurtz. "Uniform Status of Children of Assisted Conception Act: A View from the Drafting Committee." Nova Law Review 13:2 (Spring 1989): 491-514. As more children are conceived, sustained, and delivered through the intervention of extraordinary technological procedures (specifically, in vitro fertilization and surrogacy), the need to define their legal status becomes increasingly important; "Because of an accident of birth, these children of the new biology are deprived of certain basic rights." This article presents the views and rationale of the Drafting Committee of the "Uniform Status of Children of Assisted Conception Act" (1988), a document drafted by the National Conference of Commissioners on Uniform State Laws, and adopted by that body in August, 1988, and later adopted by the ABA in February, 1989. The Act is presented with detailed commentary.

Rogers, Gaylene. "Spousal notification requirement is constitutionally permissible burden on woman's right to privacy in abortion decision." Texas Tech Law Review 13 (July 1982): 1495-1511. Central to the thesis of this article is the author's contention that Roe $v$ Wade is based in sound constitutional law. Both the ninth and the fourteenth amendments are examined in support of Roe, in which it is determined that the "right of privacy extends to termination of pregnancy." An evaluation of the debate over time of fetal viability is presented, and emphasis is placed on the question of possible state control over means of abortion. The author seeks to expand the Court's limited analysis of the woman's right to abortion, the concept of fetal development and viability, and the use of various abortion technologies.

Roggow, Curtis. "Constitutional law-states have greater latitude to regulate and restrict abortions: Webster v Reproductive Health Services, 492 U.S. 490 (1989)." (Case Note) Drake Law Review 40 (Winter 1991): 433-449.

Rothman, Barbara Katz. "Motherhood: Beyond Patriarchy." Nova Law Review 13:2 (Spring 1989): 481-486. The author contends that the legal system has a difficult time dealing with circum- 
stances that are uniquely new, that do not indicate points of attachment to ideas the law has dealt with in the past. Nowhere is this more apparent than in the hesitancy the law has shown in its understanding of family and procreation, where legal concepts seem mired in the notion of patriarchy. With the advent of technological changes in the birth process (in vitro fertilization, for example), paternity and maternity must be redefined. The author argues that motherhood implies more than a genetic relationship, and that it must be legally redefined to better deal with the social consequences of emerging technologies, especially surrogacy.

Rubin, Leslie. "Confronting a New Obstacle to Reproductive Choice: Encouraging the Development of RU-486 Through Reform of Product Liability Law." New York University Review of Law and Social Change 18:1 (1990-91): 131-159. RU-486 has gained recent notoriety as an "abortion pill." While used in Europe, it has not been made available in the United States because of intense opposition by anti-choice groups. The author sees the use of RU-486 as a way to help women control their lives insofar as enabling them to make choices regarding childbirth. The purpose of the article is to "examine ways to limit the potentially excessive liability of would-be manufacturers of RU-486 through the adopting of various legal reforms in order to encourage development of the drug. Given that the mechanism of tort law currently imposes such massive potential liability on manufacturers of certain classes of drugs. The author contends that changes in the law are the only means by which to assure such necessary medications are marketed. The primary approach suggested is that of the no-fault compensation scheme under which people injured by a product are compensated automatically for their injuries.

Rush, Curt S. "Genetic screening, eugenic abortion, and Roe v. Wade: how viable is Roe's viability standard?" Brooklyn Law Review 50 (Fall 1983): 113-142. The author argues that eugenic abortion, that is, an abortion performed after genetic screening tests have revealed the existence of an abnormality in the fetus, should be permitted at any stage of pregnancy; especially in light 
of the "time constraints imposed by the procedure through which genetic defects in the fetus are discovered."

Rush, Sharon Elizabeth. "Prenatal caretaking: limits of state intervention with and without Roe." University of Florida Law Review 39 (Winter 1987): 55-111.

Rutherford, Jane. "Beyond Individual Privacy: a New Theory of Family Rights." University of Florida Law Review 39:3 (Summer 1987): 627-652. Traces the changes that have occurred in American family law over the last twenty years. Points out that while we have moved away from protecting the family, we have not developed a new model to explain the changes. The author argues that we have moved from being pro-family to emphasizing individualism and individual rights. Examples cited are: no-fault divorce, legalized contraception and abortion, child custody rights for unwed fathers, etc.

Schaefer, Kim. "In-vitro Fertilization, Frozen Embryos, and the Right to Privacy-Are Mandatory Donation Laws Constitutional?" Pacific Law Journal 22:1 (October 1990): 87-121. The process of in-vitro fertilization includes the creation of more embryos then may be desired by the natural mother. Some states require that all embryos that are created be implanted in either the natural mother or in another woman who is willing to have the donated embryo implanted. This requirement, the author argues, amounts to mandatory donation. The question addressed here is should the decision rest in the hands of the state, or is it a private matter to be determined by the man and woman involved.

Schnalby, Stephen J. "Normative judgment, social change, and legal reasoning in the context of abortion and privacy." New York University Review of Law \& Social Change 13 (Fall 1985): 715-910. A lengthy and thorough consideration of the legal and ethical questions surrounding the issue of abortion. Includes much discussion of privacy rights.

Schulte, Mary Jo. "State regulation of a minor's abortion rights: where do we go from here?" (Annual Eighth Circuit Survey) (case note) Creighton Law Review 22 (Spring 1989): 1007-1034. 
Scott, Elizabeth S. "Sterilization of Mentally Retarded Persons: Reproductive Rights and Family Privacy." Duke Law Journal 1986 (November 1986): 806-865.

Shannon, Colleen. "Constitutional Law-What Ever Happened to a Woman's Fundamental Right to Privacy?: Hodgson v. Minnesota, 110 S. Ct. 2926 (1990). (Case Note) Suffolk University Law Review 25 (Spring 1991): 192-200. The Court concluded that, in spite of a cumbersome two parent notification clause, the statute was constitutional because it provides for a judicial bypass of the notification clause.

Shaw, Patricia Swearingen. "Constitutional law-abortion protest first amendment speech rights outweigh privacy rights of women seeking abortions." (case note) Cumberland Law Review 20 (Fall 1989): 183-194.

Shore, Brian D. "Marital secrets: the emerging issue of abortion spousal notification laws." Journal of Legal Medicine 3 (September 1982): 461-482.

Smith, George P. II and Robert Inaola. "Sexuality, Privacy and the New Biology." Marquette Law Review 67 (Winter 1984): 263-291. The authors argue that a woman's right to privacy does not include a right to artificial insemination or to surrogation.

Smith, Philip A. "The right to privacy: Roe v. Wade revisited." The Jurist 43 (Spring 1983): 289-317.

Snedaker, Kathryn Holmes. "Reconsidering Roe v. Wade: Equal Protection Analysis as an Alternative Approach." New Mexico Law Review 17:1 (Winter 1987): 115-137.

Snyder, Douglas B. "Mother v. Fetus: the Case of 'Do or Die': In re A.C." The Journal of Contemporary Health Law and Policy 5 (Spring 1989): 319-337.

Somerville, Margaret A. "Weaving 'Birth' Technology into the 'Value and Policy Web' of Medicine, Ethics and Law: Should Policies on 'Conception' be Consistent?" Nova Law Review 13:2 (Spring 1989): 515-618. The primary concern voiced in this article is how the various medical and legal policies regarding conception may be viewed as consistent across the many new 
birth technologies now available. Values and principles relevant to the birth technology context are discussed, as is the concept of policy consistency vs inconsistency in reproduction technology situations. Finally, human rights laws, family law, and privacy considerations are examined in light of new reproduction capabilities.

Sondgrass, Teresa. "Minor's right of privacy: bypass procedures to notification statutes." Journal of Juvenile Law 10 (Spring 1989): 239-250. While the state's interest in protecting a minor female is considered to be greater than its interest in protecting an adult female, minors still have a constitutional right to privacy, and, therefore, laws regarding parental consent for abortion must allow for a means to "bypass" such requirements. That is, the minor must have the right to show that she is mature enough to make this decision without the involvement of her parents.

Spillenger, Clyde. "Reproduction and Medical Interventionism: An Historical Comment." Nova Law Review 13:2 (Spring 1989): 385-392. Presented, here, is an examination of the role medical technology has played in the reproduction process, with the primary focus on "the dangerous and fallacious view that whatever science and medical technology make possible should be implemented, by legal coercion if necessary."

Stefan, Susan. "Whose Egg is it Anyway?: Reproductive Rights of Incarcerated, Institutionalized and Incompetent Women." Nova Law Review 13 (Spring 1989): 405-456. Primarily a consideration of a special subset of women's reproductive rights, this article examines the choices of incarcerated/institutionalized women regarding aspects of conception, pregnancy, childbirth and parenthood.

Sullivan, Shannon S. "Maternal Liability: Courts Strive to Keep Doors Open to Fetal Protection-But Can They Succeed?" John Marshall Law Review 20:4 (Summer 1987): 747-768. This note contends that "the imposition of a maternal duty of care is not compatible with the present state of the law concerning a woman's rights" in light of Roe $v$ Wade. The author examines common law fetal rights, as well as tort law rights. She considers the state and personal interests involved, especially in light of 
recent cases regarding child abuse and neglect statutes, and concludes that the maternal duty of care should not be imposed through civil or criminal measures, except in life-saving situations.

Taylor, Abbi S. "Webster v. Reproductive Health Services: What remains of the right to choose?" (case note) Mercer Law Review 41 (Winter 1990): 769-788. The author presents the background of the right to privacy, including the right to choose abortion; and then goes on to analyze Supreme Court cases decided subsequent to the Roe decision, up to and including Webster.

Taylor, Elizabeth G. "Constitutional Limitations on State Intervention in Prenatal Care." Virginia Law Review 67 (June 1991): 1051-1067. "This note explores the constitutional limits on the power of states to intervene in an expectant mother's health care decisions." The author concludes that if state requirements or restrictions on a pregnant woman's behavior result in the prevention of damage to the health of the fetus, then they are constitutional.

Terry, Nicolas P. "Politics and privacy: refining the ethical and legal issues in fetal tissue transplantation." (Symposium on Fetal Tissue Transplantation) Washington University Law Quarterly 66 (Summer 1988): 523-551. The author points out the inevitability of the linking of fetal tissue transplantation with the debate surrounding abortion, and suggests that if judges and policymakers have locked themselves into positions on this issue because of their stance on abortion, then it may be that the debate on fetal tissue use actually ended before it began.

Tobias, Carl. "Intervention after Webster." University of Kansas Law Review 38 (Spring 1990): 731-766. Discusses the fact that the Webster decision is, in effect, an open invitation to the state legislatures to place restrictions on a woman's right to choose to have an abortion. The author then analyzes the procedural problems that may be faced by individuals or groups who attempt to intervene between an individual woman and her right to choose.

"Too close for comfort: protesting outside medical facilities." Harvard Law Review 101 (June 1988): 1856-1875. The author argues that the "bubble zone protection" created by a Boulder ordi- 
nance to protect the privacy rights of patients entering or exiting medical facilities in which abortions are performed "is an appropriate and permissible means of balancing the rights of speakers against the privacy interests of certain unwilling listeners." The ordinance creates an area around the individual, eight feet in this case, within which the person cannot be approached without her permission.

Wardle, Lynn D. "Rethinking Roe v. Wade." Brigham Young University Law Review 1985 (Spring 1985): 231-264. Provides background information about the Roe decision, and argues that the decision should be reconsidered in light of changes in society and medical technology.

Werth, Meera. "Spousal notification and the right of privacy." Chicago-Kent Law Review 59 (Fall 1983): 1129-1151.

Westfall, David. "Beyond abortion: the potential reach of a human life amendment." American Journal of Law and Medicine 8 (Summer 1982): 97-135. "This article focuses on the implications of proposed amendments that seek to ban or limit the availability of abortions indirectly by broadening the definition of "person" to include unborn individuals." The author goes on to discuss the potentially detrimental effects such an amendment would have in areas unrelated to abortion.

Wikler, Daniel. "Abortion, Privacy, and Personhood: From Roe v. Wade to the Human Life Statute." In Abortion: Moral and Legal Perspectives. Amherst, Mass.: University of Massachusetts Press, 1984, pp. 238-259. Includes bibliography.

Wing, Kenneth R. "The Supreme Court's spring term: abortion, the right to die, and the decline of privacy rights." Journal of Health Politics, Policy and Law 15 (Winter 1990): 919-928.

Wolff, Morris H. and Robert H. Hawn, Jr. "H. L. v. Matheson and the right of minors to seek abortions." California Western Law Review 19 (Fall 1982): 74-106.

Wyk, Julie Van. "Constitutional law-Minnesota Department of Health release of names of medical assistance abortion providers held not violative of a patient's right of privacy." Western New England Law Review 2 (Winter 1980): 569-591. 